\title{
水に分散可能な無機 Si クラスターを活用した水溶液プロセスによるケイ酸塩蛍光体の合成
}

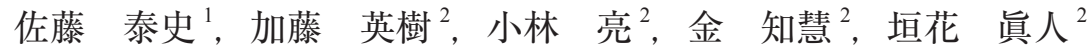 \\ ${ }^{1}$ 東北大学多元物質科学研究所 [現：岡山理科大学理学部化学科, $\bar{T} 700-0005$ 岡山市北区理大町 1-1]. \\ ${ }^{2}$ 東北大学多元物質科学研究所, $\overline{\mathrm{T}} 980-8577$ 仙台市青葉区片平 2-1-1.
}

\section{Syntheses of Silicate Phosphors by Aqueous Solution Techniques using Water-Dispersible Inorganic Si Cluster}

\author{
Yasushi SATO ${ }^{1}$, Hideki KATO ${ }^{2}$, Makoto KOBAYASHI ${ }^{2}$, Jihae $\mathrm{KIM}^{2}$ and Masato KAKIHANA ${ }^{2}$ \\ ${ }^{1}$ Institute of Multidisciplinary Research for Advanced Materials, Tohoku University \\ [Present Address: Department of Chemistry, Faculty of Science, Okayama University of Science, 1-1 Ridai-cho, Kita-ku, Okayama 700-0005, Japan]. \\ ${ }^{2}$ Institute of Multidisciplinary Research for Advanced Materials, Tohoku University, 2-1-1 Katahira, Aoba-ku, Sendai 980-8577, Japan.
}

Received November 15, 2014

\begin{abstract}
In this paper, we demonstrated the synthesis of silicate-based phosphors by solution techniques using glycolmodified silane (GMS) as a Si source. GMS is a water-dispersible inorganic Si cluster, which is vitally involatile and nonflammable compounds, compared to volatile and flammable Si-alkoxides such as tetraethoxysilane (TEOS). Therefore, GMS has allowed the silicon containing compounds to be synthesized through various solution processes for ceramic compounds such as polymerizable complex (PC) and amorphous metal complex (AMC) methods. This paper provides examples of synthesis of new silicate-based phosphors such as $\mathrm{NaAlSiO}_{4}$ : $\mathrm{Eu}^{2+}$, $\mathrm{BaZrSi}_{3} \mathrm{O}_{9}: \mathrm{Eu}^{2+}$, and $\mathrm{CaSrSiO}_{4}: \mathrm{Eu}^{2+}$. In addition, other examples of improvement of emission for conventional silicate-based phosphors, $\mathrm{Y}_{2} \mathrm{SiO}_{5}: \mathrm{Ce}^{3+}-\mathrm{Tb}^{3+}$ and $\mathrm{Zn}_{2} \mathrm{SiO}_{4}: \mathrm{Mn}^{2+}$, prepared by the above solution techniques including homogeneous precipitation using GMS are also given in this paper.
\end{abstract}

KEY WORDS

glycol-modified-silane (GMS), solution parallel synthesis, mineral, exploration of new phosphors, silicate.

\section{1 緒言}

蛍光体材料は，古くからテレビ用ブラウン管や照明用蛍光 ランプを中心に広く利用されてきたが，近年，テレビ用ブラ ウン管の衰退と白色 LED ランプの急速な普及の拡大に伴い, その用途は主に白色 LED 素子用蛍光体へと移行している ${ }^{1-5)}$. 特に青色 LEDの青色光での励起によって黄色〜赤色領域に 強発光を示す蛍光体の開発は, 白色 LED ランプへの応用 の面からも強く望まれている。このような観点から，4f-5d

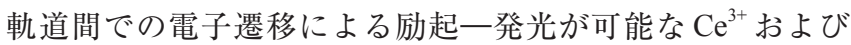
$\mathrm{Eu}^{2+}$ を発光イオンとし, $\mathrm{Si}$ を含む酸化物, 窒化物, 酸窒化物 をリード物質とした材料群が精力的に研究されている ${ }^{1-7)}$.

現在の蛍光体に関する研究・開発は, 大きく分けて 2 つの 目標を設定することができる。一つ目は，「蛍光体の特性最 適化」という点である. 白色 LED 応用では, 主に蛍光体の 高効率化や可視光領域での波長制御といった実用的な性能を 有する蛍光体の最適化が焦点になる。つまり，既知の実用 的な蛍光体をべースにして, 発光イオン濃度の最適化や母体
となるリード物質に対する元素置換, さらに合成プロセスの 開発・改良による高純度・高品質試料粉末の製造といった検 討が該当する。 二つ目は,「蛍光体の新物質探索」という点 である．新しい優れた性能を有する蛍光体をどのようにして 探すかが焦点になる．既知の蛍光体を大きく上回る輝度を有 する蛍光体や既知蛍光体の発光波長では手薄な波長域（例え ば，白色 LED 応用では， $500 \mathrm{~nm}$ 前後の青緑色領域や $650 \mathrm{~nm}$ 前後の深赤色領域）において強い発光を示す蛍光体の発見が 挙げられる。ささに $\mathrm{Eu}$ や $\mathrm{Tb}$ などの希少かつ高価な元素を使 わずに，ありふれた沉用元素を中心に構成された新しい蛍光 体の新規探索も挙げられる.

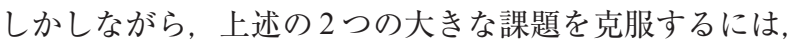
いくつかの問題をクリアにしていく必要がある. 現行の蛍光 体では，(1)典型なリード物質であるケイ酸塩の高純度合成法 とその簡略化，(2)発光源となる発光中心イオン（賦活剂）の リード物質での均一分散方法, (3)新規蛍光体探索における探 索の指導原理，(4)効率的な候補物質のスクリーニング技術, 
といった点が明確に確立されておらず，蛍光体の研究・開発 を遅延させる要因にもなっている。

そこで我々のグループでは，これらの課題を解決するため， まず「蛍光体をつくる」という点については, 水に分散可能 なグリコール修飾シラン（GMS = Glycol-Modified-Silane）を 活用した水溶液プロセスを開発し，従来合成が困難であった ケイ酸塩系蛍光体の高純度合成と高度機能化, 賦活剤の均一 分散性の向上を試みた ${ }^{8,9}$. また，「蛍光体をさがす」という 点については，まず蛍光体探索の指導原理として，“鉱物資 源の中に新規蛍光体のヒントが隱されている”との信念のも と,「鉱物にヒントを得た溶液並列合成法による新蛍光体探 索」という戦略を打ち出し，天然鉱物をべースにした人工組 成のライブラリーを作成し，有望な候補物質を絞り込む事を 提案するとともに，これらの候補物質を効率的に合成する手 法として「溶液並列合成法」による合成法を考案した ${ }^{10-12)}$.

この「溶液並列合成法」は複雑な組成のセラミックスの均一 合成に優れる錯体重合法 ${ }^{13)}$ やアモルファス金属錯体法 ${ }^{14)}$ を用 いて，同じ条件で一度に数十種類の試料を合成する手法であ り，GMS を含む溶液プロセスに適した原料を併用すること で, 従来研究では実現困難であったケイ酸塩系蛍光体候補物 質の効率的なスクリーニングを可能にし，新しいケイ酸塩系 蛍光体を見出すことが可能になった

このように, 我々の蛍光体研究において重要な役割を果 たすものが $\mathrm{Si}$ 源となる GMS である，本稿では，まず，プ ロピレングリコールを配位させたPGMS（Propylene-GlycolModified-Silane）を用いた水に分散可能な無機 $\mathrm{Si}$ クラスター を活用した水溶液プロセスによる蛍光体合成と高度機能化に ついて, これまでの当グループの研究例を紹介する. 加えて, 鉱物にヒントを得た溶液並列合成法による新蛍光体探索につ いて，PGMS を利用した研究例も併せて紹介する。

\section{GMS の特徵と合成方法, $8,914-22)$}

これまで Si を含むセラミックスの合成プロセスとしては, 簡便な原料粉末同士を混合した固相反応法や混合した原料粉 末を溶融しアニール処理による結晶化する方法，さらに揮発 性・可燃性の高い金属アルコキシドを原料としたゾルゲル法 などが挙げられる。一方，これまで超伝導セラミックスなど の高純度試料の合成法として広く知られてきた錯体重合法や アモルファス金属錯体法などの水溶液プロセスによるケイ酸 塩物質の検討は，水溶液に溶解もしくはクラスターレベルで 分散できる $\mathrm{Si}$ 原料がほぼ皆無であったことから，コロイダ ルシリカといった微粒子を $\mathrm{Si}$ 源として使用した例を除き，

ほとんど存在しない。これに対して，GMSは，水溶液中に クラスターレベルで均一に分散できる大変珍しい $\mathrm{Si}$ 原料で ある. Fig. 1 にPGMS の合成フローならびに予想される反応 経路を示す ${ }^{8,9,15)}$.

プロピレングリコール $(\mathrm{PG})$ とテトラエトキシシラン $(\mathrm{TEOS})$ を少量の $\mathrm{H}^{+}$共存下, $80^{\circ} \mathrm{C}$ で加熱摚拌すると, TEOS のエト キシ基と PG との置換基交換反応が進行し, PGMS が生成す る. 疎水性である TEOS と親水性のPG だけを混合した場合,
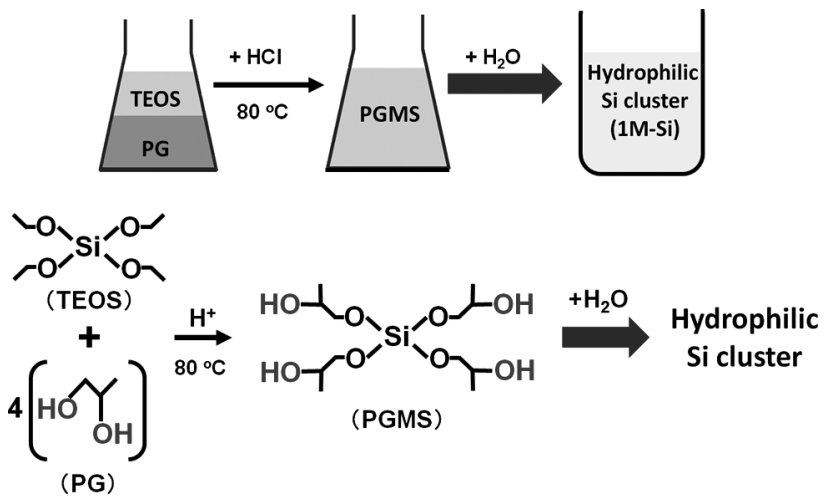

Fig. 1 Flowchart of experimental procedures for preparation of propylene glycol modified sliane dispersed in aqueous solution. Chemical structures of PGMS, TEOS and PG are also shown in this figure.

両者は互いに混ざらず二層分離する。一方，ここに触媒とし て塩酸や硝酸といった無機酸を少量添加すると，上記の置換 基交換が起こり，一層のPGMS が形成される，そして，得 られたPGMS を水に投入すると, PGMS は直ちに加水分解 を受けケイ素クラスターを形成し，水中で均一に分散した状 態となる. PGMSは, 水と共存した状態では室温で放置して いると徐々に縮合反応が進行し，最終的にゲル化してしまう が，PGMS を水に分散させた後，冷蔵保存した上，短期間で 合成に使用することで，水溶液プロセスにも十分対応可能な $\mathrm{Si}$ 原料となる。つまり，一定の $\mathrm{Si}$ 濃度（通常は $1 \mathrm{~mol} / \mathrm{L}-\mathrm{Si}$ ) に調整したPGMS 溶液と各種金属水溶液を，錯体重合法や アモルファス金属錯体法の原料溶液に用いることで，簡便か つ高純度・高品質のケイ酸塩セラミックス粉末を合成するこ とができる，なお， GMS は，PG 以外のグリコール，例えば エチレングリコール，1-4 ブタンジオールなどを用いても合 成可能である。

\section{GMS を用いた蛍光体合成の研究紹介}

ここでは，PGMS を用いた我々のグループによるこれまで の蛍光体合成の研究例をいくつか紹介する.

3.1 溶液並列合成法による $\mathrm{Y}_{2} \mathrm{SiO}_{5}: \mathrm{Ce}^{3+}-\mathrm{Tb}^{3+}$ 蛍光体での増感 イオンと発光イオンの最適濃度の決定"

蛍光体の発光特性は, リード物質に微量ドープした希土類 などの発光イオンの分散性と濃度が強く影響する。一般に蛍 光体の発光強度は発光イオン濃度の増加に伴い強くなるが, ある濃度を超えると濃度消光と呼ばれる強度低下が生じる。 これには，(1)発光イオン自身による発光の吸収，(2)発光イオ ン同士の距離の減少に伴うイオン間でのエネルギー移動の増 加，という2つの要因が考えられる。つまり，リード物質へ の発光イオンが不均一に分散した場合，リード物質内に発光 イオン濃度の濃淡ができ, 局所的に濃度の高い箇所では濃度 消光が起こり, 結果として蛍光体の発光強度低下が生じる. 一般的な固相反応法では，原料粉末はミクロレベルでの混合 となるため, この方法で合成された試料における発光イオン の分散性は, 原料の粒径や拡散能の影響から低くなることが 知られている。 つまり，固相反応法で合成した試料による発 
光イオンの最適濃度の決定は非常に困難であるといえる。こ れに対して，水溶液プロセスでは構成イオンを原子レベルで 化学混合するため, 得られた前駆体を適切な温度で焼成する ことで，発光イオンが均一に分散された蛍光体を合成するこ とができる。ここでは, $\mathrm{Y}_{2} \mathrm{SiO}_{5}: \mathrm{Ce}^{3+}-\mathrm{Tb}^{3+}$ 蛍光体に対する水 溶液法を利用した発光イオンの最適濃度の決定と均一分散に 関する取り組みを紹介する。

$\mathrm{Y}_{2} \mathrm{SiO}_{5}: \mathrm{Ce}^{3+}-\mathrm{Tb}^{3+}$ は, $\mathrm{Ce}^{3+}$ の $4 \mathrm{f}-5 \mathrm{~d}$ 遷移に関係する強い光吸 収を利用し, $\mathrm{Ce}^{3+}$ の励起エネルギーを $\mathrm{Tb}^{3+}$ へ移動させること で, $\mathrm{Tb}^{3+}$ の 4f-4f 遷移に伴う強い緑色発光 $\left(\mathrm{Tb}^{3+}\right.$ の $\left.{ }^{5} \mathrm{D}_{4} \rightarrow{ }^{7} \mathrm{~F}_{5}\right)$ を与える蛍光体である ${ }^{23)}$. この蛍光体の高輝度化には, $\mathrm{Ce}^{3+}$ から $\mathrm{Tb}^{3+}$ への効率的なエネルギー移動と $\mathrm{Tb}^{3+}$ の濃度消光の 抑制が重要であり,これまでに $\mathrm{Ce}^{3+}$ および $\mathrm{Tb}^{3+}$ の最適濃度 は上記の固相反応法により決定されていたが，その信頼性に は問題があった。 そこで，リード物質内での $\mathrm{Ce}^{3+} / \mathrm{Tb}^{3+}$ の最適 な比率を検討するため, 約 30 通りもの $\mathrm{Ce}^{3+}$ と $\mathrm{Tb}^{3+}$ 濃度の比 率の組み合わせを用意し，PGMS ならびに $\mathrm{Y}, \mathrm{Ce}, \mathrm{Tb}$ の各錯 体水溶液を用いて溶液並列合成法により，各組成の試料合成 を行った（Fig. 2)。その結果，得られた試料の発光強度の強 さから, $\mathrm{Y}_{2} \mathrm{SiO}_{5}$ 系における最適な $\mathrm{Ce}^{3+} / \mathrm{Tb}^{3+}$ 比率を絞り込み, $\mathrm{Ce}^{3+} / \mathrm{Tb}^{3+}=0.015 / 0.115$ の試料の発光強度が最も高いことを明 らかにした.さらに, この最適組成 $\left(\mathrm{Ce}^{3+} / \mathrm{Tb}^{3+}=0.015 / 0.115\right)$ の試料について錯体重合法（PC）を用いて合成し, 同じく 固相反応法（SSR）を用いて合成した試料との比較を行った ところ，錯体重合法を用いて合成した試料の発光強度は，固 相反応法の試料に比べて 10 倍以上も高い発光強度を示すこ とを確認した (Fig. 3).

このように，溶液並列合成法を用いることで， $\mathrm{Y}_{2} \mathrm{SiO}_{5}$ 蛍 光体に扔いて最適な $\mathrm{Ce}^{3+} / \mathrm{Tb}^{3+}$ の濃度比を決定することに成 功した，上述の結果は，従来では不可能であったケイ酸塩蛍 光体での正確な発光イオン濃度の決定において，PGMS を用 いた溶液並列合成法が極めて有用であることを示した例とい える.

3.2 溶液並列合成法に上る新規ケイ酸塩蛍光体物質の探索 ${ }^{10,19,2,24}$ 蛍光体の新規物質探索において, 発光に適した結晶サイト を有するリード物質の選択は非常に重要である。しかしなが ら，無機化合物の場合，製薬開発の分野で広く利用されてい るコンビナトリアル合成の概念をそのまま適用する事は困難 であり，スクリーニングを行うことで候補となるリード物質 の選定条件を設けた上で検討する必要がある。 そこで，我々 のグループでは，長年にわたり蓄積された天然鉱物や無機化 合物に関するデータベースを活用することで，結晶化学的知 見に基づいた人工組成を提案し，この人工組成をベースにし た組成ライブラリーを作成し，新規蛍光体物質の探索を進 めてきた，例えば，1つの人工組成について，まず電荷，イ オン半径, 化学的性質を考慮した元素置換や $\mathrm{Eu}^{2+} や \mathrm{Ce}^{3+}$ と いった賦活剂の種類や添加量の変化から組成ライブラリーを 作成し，このライブラリーに基づき合成を進めていく，この ように多数の蛍光体組成を短時間でスクリーニングする必要 があり，粉末同士を混合する従来の固相反応法による合成は

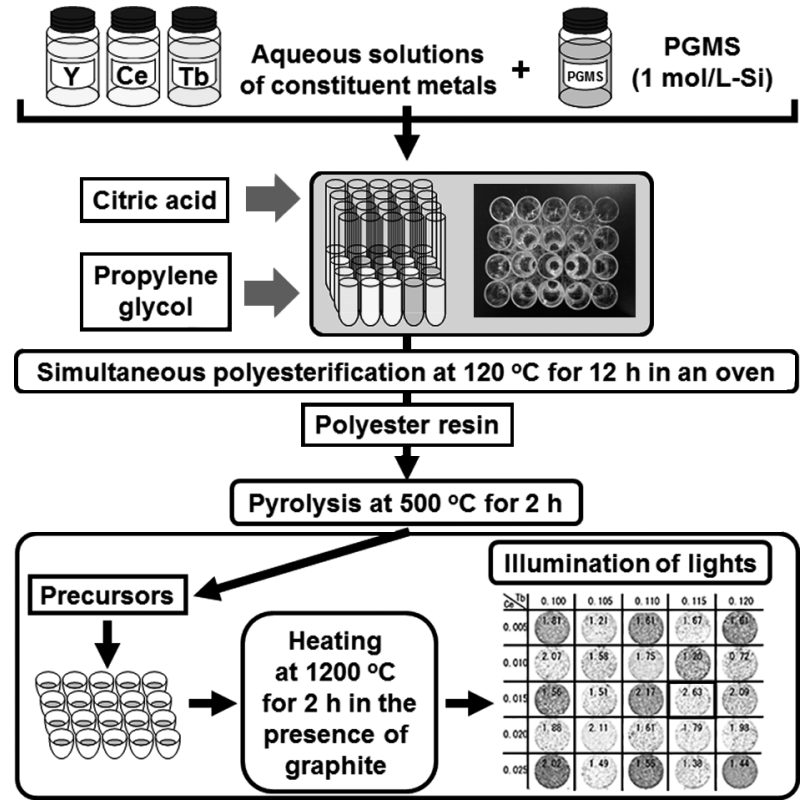

Fig. 2 Scheme of solution parallel synthesis for the optimumzation of $\mathrm{Ce}^{3+}$ and $\mathrm{Tb}^{3+}$ concentrations in $\mathrm{Y}_{2} \mathrm{SiO}_{5}: \mathrm{Ce}^{3+}-\mathrm{Tb}^{3+}$ phosphors. GMS was used as the silicon source. Visual observation of emission light by illumination with near-UV light is also shown as the image.

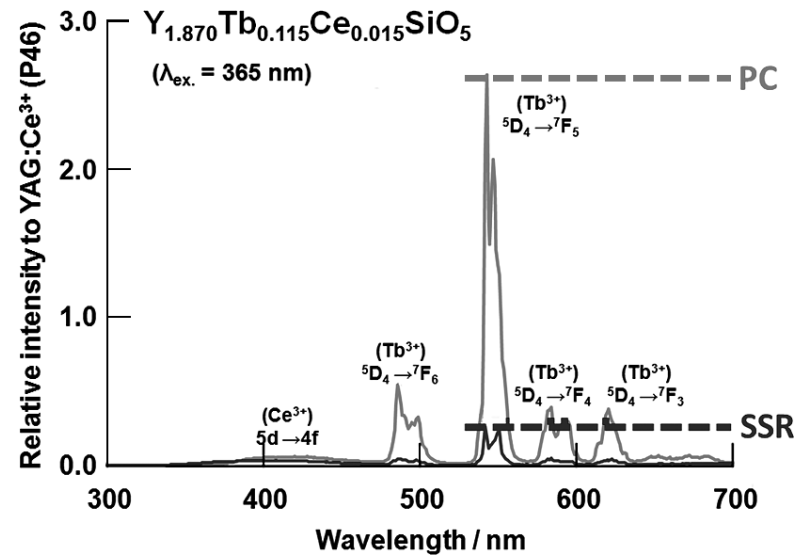

Fig. 3 Emission spectra of $\mathrm{Y}_{1.870} \mathrm{~Tb}_{0.115} \mathrm{Ce}_{0.015} \mathrm{SiO}_{5}$ prepared by the polymerizable complex (PC) method and by the solid-state reaction (SSR) method. Excitation wavelength was $356 \mathrm{~nm}$.

効率が悪く適さない，一方，溶液並列合成法では，各金属成 分のストック溶液を用意し，ピペットを用いて採取すること で組成制御を容易に行うことができる．よって，この方法 は，複数の組成をスクリーニングする上で大変有用である. Fig. 2 と同様に, PGMS と各金属塩水溶液を用いることで, $\mathrm{Si}$ ベースの蛍光体物質のスクリーニングが可能になる.なお, 溶液並列合成法による新物質探索の詳細ならびにこれまでの 実施例については, 参照に挙げた文献を参考されたい ${ }^{10,19,22,24)}$. 今回は，一例としてケイ酸塩蛍光体である $\mathrm{NaAlSiO}_{4}: \mathrm{Eu}^{2+}$ 系 を取り上げる ${ }^{199}$.

$\mathrm{NaAlSiO}_{4}: \mathrm{Eu}^{2+}$ のリード物質は霞石（Nepheline）と呼ばれ る鉱物であり，当グループに扔いて考案した“ケイ酸ナト リウム・アルミニウム系鉱物”の人工組成群（計 30 組成） の中に含まる．Fig. 4 に $\mathrm{NaAlSiO}_{4}: \mathrm{Eu}^{2+}$ の発光特性を示す。ま 


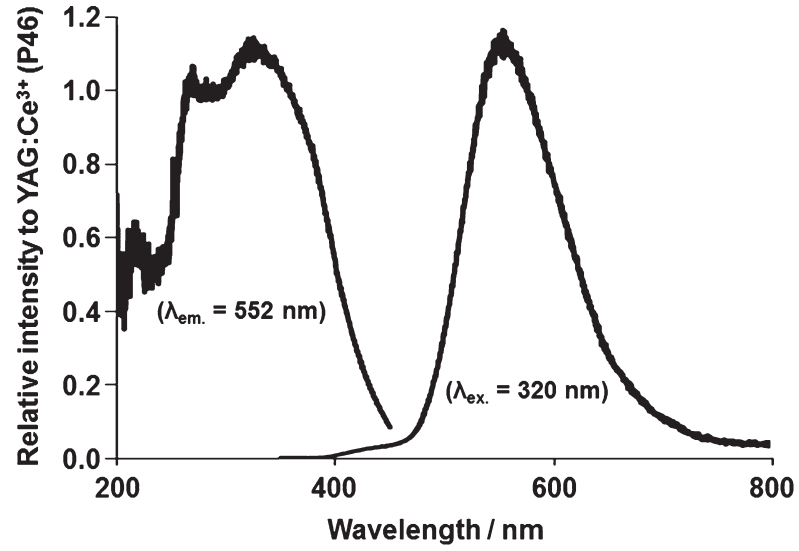

Fig. 4 Excitation and emission spectra of $\mathrm{NaAlSiO}_{4}: \mathrm{Eu}^{2+}(1 \mathrm{~mol} \%$ for $\mathrm{Na})$ discovered by employing solution parallel synthesis method.

ず，この蛍光体は，近紫外領域の光により励起が可能であ り，最大励起波長は $320 \mathrm{~nm}$ であることわかる，そして，試 料を波長 $320 \mathrm{~nm}$ で励起した場合，波長 $553 \mathrm{~nm}$ を最大発光波 長とする強い黄緑色発光が観測され, その発光強度は市販

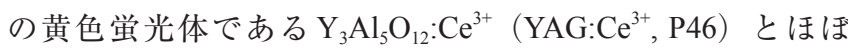
同等であった。この $\mathrm{NaAlSiO}_{4}: \mathrm{Eu}^{2+}$ 系は, 当グループの発見 とほほ同時期に韓国・成均館大学＋新潟大学グループから も報告されているが25)，それ以前の研究報告はなく, 全く新 しい蛍光体物質といえる。 また, 我々は, この系をべース に， $\mathrm{Na}^{+}$を 価の $\mathrm{Mg}, \mathrm{Ca}, \mathrm{Sr}$ に，また電荷のバランスをと るため, $\mathrm{Si}^{4+}$ を 3 価 $\mathrm{Al}^{3+}$ に置き換えた電荷補償型組成につい ても溶液並列合成法による検討を行った ${ }^{19)}$. その結果, $\mathrm{Na}^{+}$ の一部を $\mathrm{Mg}^{2+}$ に, $\mathrm{Si}^{4+}$ の一部を $\mathrm{Al}^{3+}$ でそれぞれ置換した系 $\left(\mathrm{Na}_{0.9} \mathrm{Mg}_{0.1} \mathrm{Al}_{1.1} \mathrm{Si}_{0.9} \mathrm{O}_{4}: \mathrm{Eu}^{2+}\right)$ では，未置換系 $\left(\mathrm{NaAlSiO}_{4}: \mathrm{Eu}^{2+}\right)$ に比べて, さらに約 1.3 倍も高い発光を示すことを見出した. このように，我々が提案した天然鉱物をヒントにした物質探 索の指針と PGMS を利用した溶液並列合成法の組み合わせ は，新規蛍光体物質を効率的に探索する上で非常に有効であ ることがわかる.

なお，我々は，さらにケイ酸ジルコニウム系鉱物の人工 組成群（計 49 組成）について溶液並列合成法を用いてスク リーニングを行ったところ, ベニト石系列の鉱物をリード物 質とした $\mathrm{BaZrSi}_{3} \mathrm{O}_{9}: \mathrm{Eu}^{2+}$ という組成を見出した ${ }^{24)}$.この蛍光 体は, 紫外光〜近紫外光照射下で目視可能な非常に強い青緑 色の発光を示し，市販の青色蛍光体である $\mathrm{BaMgAl}_{10} \mathrm{O}_{17}: \mathrm{Eu}^{2+}$ に匹敵する強い発光強度を示すことを確認している.

3.3 均一沈殿法による $\mathrm{Zn}_{2} \mathrm{SiO}_{4}: \mathrm{Mn}^{2+}$ 蛍光体の高純度合成 ${ }^{18)}$

均一沈殿法は, 加熱により尿素などの加水分解をおだやか に進行させることで溶液中の $\mathrm{pH}$ を均一に変化させて均質な 沈殿を得る方法であるが，これまで適用可能な水溶性 $\mathrm{Si}$ 原 料がなく, Si 含有セラミックスを均一沈殿法により合成する ことは困難であった。 これに対して, 我々のグループでは, PGMS を Si 原料として用いた場合, 均一沈殿法による Si 含 有セラミックスの合成が可能になることを見出した ${ }^{18)}$. ここ では, ブラウン管や蛍光灯，プラズマディスプレイパネルを はじめとして工業的に広範に用いられてきた $\mathrm{Zn}_{2} \mathrm{SiO}_{4}: \mathrm{Mn}^{2+}$ 緑

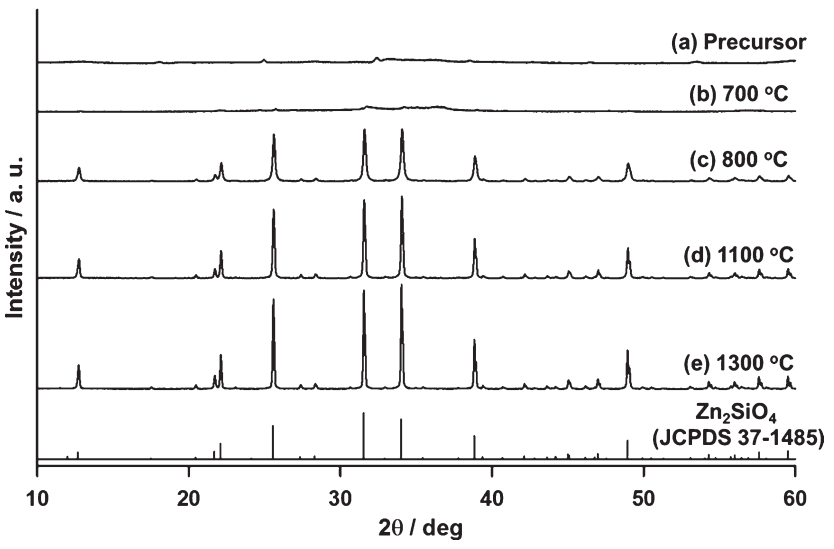

Fig. 5 X-ray diffraction patterns of $\mathrm{Zn}_{2} \mathrm{SiO}_{4}: \mathrm{Mn}^{2+}$ phosphors prepared by homogeneous precipitation (HP) using PGMS; (a) precursor and after annealing at (b) 700 , (c) 800 , (d) 1100 and (e) $1300^{\circ} \mathrm{C}$. The standard diffraction pattern of $\mathrm{Zn}_{2} \mathrm{SiO}_{4}$ (JCPDS 37-1485) was also shown as reference (f). The heat treatment time was $2 \mathrm{~h}$ for all cases. The concentration of urea was $4.5 \mathrm{~mol}$.

色蛍光体について ${ }^{26,27)}$, 均一沈殿法による合成を例として取 り上げる ${ }^{18)}$.

初めに, PGMS を用いた均一沈殿法による $\mathrm{Zn}_{1.96} \mathrm{Mn}_{0.04} \mathrm{SiO}_{4}$ 粉末の合成手順を簡単に説明する。まず，原料である $\mathrm{Zn}\left(\mathrm{NO}_{3}\right)_{2}$ 水溶液, $\mathrm{Mn}\left(\mathrm{NO}_{3}\right)_{2}$ 水溶液, PGMS (1M-Si) を所望の組成に なるように採取し，続いて，沈殿凨である尿素またはへキサ メチレンテトラミン（HMT）を加え，ビーカー内でよく混 合した，この際，純水を加えることで， Zn， Mn, Si の合計 濃度を $0.1 \mathrm{~mol}(75 \mathrm{~mL})$ に調整した。 そして, 混合水溶液に $\mathrm{HCl}$ を添加し, 初期 $\mathrm{pH}$ を 2.5 に調整した。 ビーカーにふたを し, 溶液温度が $90{ }^{\circ} \mathrm{C}$, 擋拌速度が $400 \mathrm{rpm}$ となるように湯 浴を用いて加熱を行ったところ，時間の経過とともに白い沈 殿が析出した。なお，加熱により $\mathrm{Zn}^{2+}$ が析出する $\mathrm{pH}$ まで比 較的短時間で上昇させることで, 所望の組成を得ることがで きた。 そして, 得られた沈殿をろ過し蒸留水で洗浄・乾燥さ せた後, $1100{ }^{\circ} \mathrm{C}$ および $1300{ }^{\circ} \mathrm{C} て ゙$ 焼成することで最終生成物 を得た. Fig. 5 に均一沈殿法を用いて作製した $\mathrm{Zn}_{1.96} \mathrm{Mn}_{0.04} \mathrm{SiO}_{4}$ 粉末の X 線回折パターンを示す。前駆体および $700{ }^{\circ} \mathrm{C} て ゙$ 焼 成した試料のパターンは, 明瞭なピークを示さないアモル ファスであるが, $800{ }^{\circ} \mathrm{C}$ でアニールした試料は $\mathrm{Zn}_{2} \mathrm{SiO}_{4}$ 単相 のパターンを示し, さらに高温下での焼成では, 結晶性の向 上に伴い $\mathrm{Zn}_{2} \mathrm{SiO}_{4}$ 相の回折ピークはシャープになるとともに

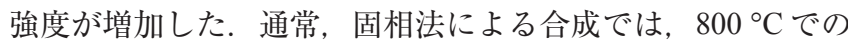
焼成後の試料には原料の $\mathrm{ZnO}$ が残存しており, $\mathrm{Zn}_{2} \mathrm{SiO}_{4}$ の単 相を得るためには $1100{ }^{\circ} \mathrm{C}$ 以上での焼成が必要であった。つ まり, PGMS を用いた均一沈殿法では, $\mathrm{Zn}_{2} \mathrm{SiO}_{4}$ 単相試料を より低温で合成することが可能である.

次に, これらの試料の発光特性を評価した. Fig. 6 に均一 沈殿法（HP）で前駆体を作製し $1100{ }^{\circ} \mathrm{C}$ およ゙ $1300{ }^{\circ} \mathrm{C} て ゙$ 焼 成した $\mathrm{Zn}_{1.96} \mathrm{Mn}_{0.04} \mathrm{SiO}_{4}$ 粉末の励起・発光スペクトルを示す.

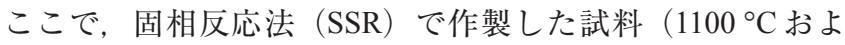
び $1300{ }^{\circ} \mathrm{C}$ で焼成）の励起・発光スペクトルも比較として併 せて示す。いずれの $\mathrm{Zn}_{2} \mathrm{SiO}_{4}: \mathrm{Mn}^{2+}$ 粉末も235-260 nm の紫外 


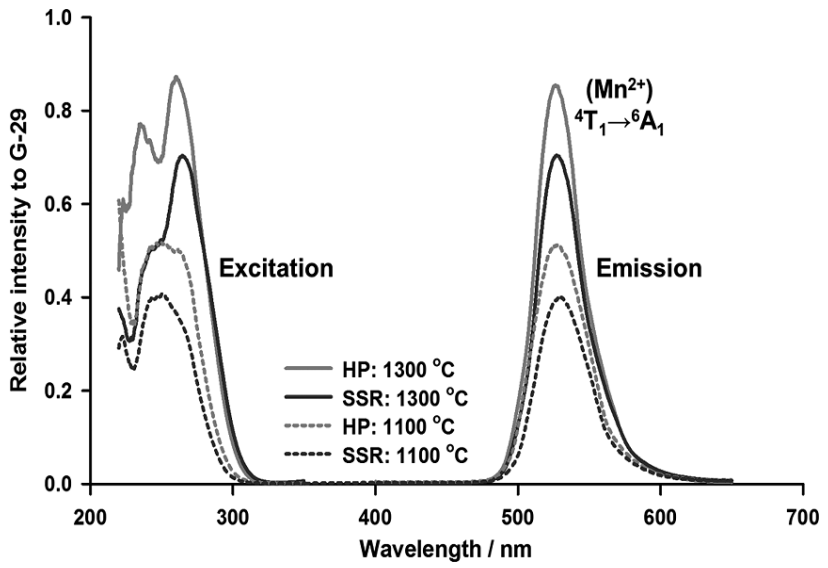

Fig. 6 Excitation and emission spectra of $\mathrm{Zn}_{2} \mathrm{SiO}_{4}: \mathrm{Mn}^{2+}$, HP samples annealed at (a) 1100 and (b) $1300{ }^{\circ} \mathrm{C}$, and SSR samples calcined at (c) 1100 and (d) $1300^{\circ} \mathrm{C}$. All the emission itensities were normalizaed by the emission intensity of commercial $\mathrm{Zn}_{2} \mathrm{SiO}_{4}: \mathrm{Mn}^{2+}$ phosphors (G-29).

光で励起したところ, $\mathrm{Mn}^{2+} の^{4} \mathrm{~T}_{1}{ }^{-}{ }^{6} \mathrm{~A}_{1}$ のエネルギー遷移に由 来する $523 \mathrm{~nm}$ にピークをもつ幅広い発光を示す．さらに， 均一沈殿法および固相法による試料はいずれも焼成温度が高 くなるに従い発光強度が強くなった，これは，高温焼成によ る結晶性の向上が要因であると考えられる。しかしながら, いずれの焼成温度に扔いても均一沈殿法で合成した試料の 方が強い発光を示し, $1300{ }^{\circ} \mathrm{C}$ で焼成した均一沈殿法の試料 は, 同温度で合成した固相法の試料の 1.2 倍の発光強度を示 した。この結果は，両合成法で作製した試料は同程度の結晶 性を有するものの, 均一沈殿法による試料では賦活剤となる $\mathrm{Mn}^{2+}$ の分散性が高いために高輝度化が達成されたためだと 解釈できる。

\section{4 凍結乾燥法による青色励起・赤色発光を示すシリケート} 蛍光体の開発 ${ }^{21)}$

最後に, PGMS を利用した水溶液プロセスと凍結乾燥法を 用いることで, ケイ酸塩化合物として大変珍しい青色励起可 能な赤色発光を示す蛍光体を見出したので紹介する。ここで 用いた凍結乾燥法は, 主に食品加工分野で広く使われ, 真空 減圧下での水の昇華現象を利用し，水分を取り除く方法であ る.この方法を用いることで, 食品を長期に保存することが 可能になる。 この方法をセラミックス材料の合成に利用する 場合，水溶液から金属成分を偏析することなく固形化でき，

金属成分が原子レベルで均一に分散した前駆体を作製するこ とができる。したがって、リード物質中に発光イオンを均一 に分散させることが求められる蛍光体の製造法として有用な 方法だと言える. $\mathrm{CaSrSiO}_{4}: \mathrm{Eu}^{2+}$ は, 紫外光から可視光領域で の波長で励起可能な蛍光体であり, 青色光励起で黄〜橙色で 発光する蛍光体として報告されてきた，今回，この系につい て, 発光イオンの分散性ならびに試料純度の向上を目指し, PGMS と凍結乾燥技術を組み合わせた水溶液プロセスによる 合成を検討した。

まず, $\mathrm{Si}$ 濃度を $1 \mathrm{~mol} / \mathrm{L}$ に調整した PGMS 溶液に, 酢酸ス卜 ロンチウム $\left(\mathrm{Sr}_{(}\left(\mathrm{CH}_{3} \mathrm{COO}\right)_{2}\right)$, 酶酸カルシウム $\left(\mathrm{Ca}\left(\mathrm{CH}_{3} \mathrm{COO}\right)_{2}\right)$

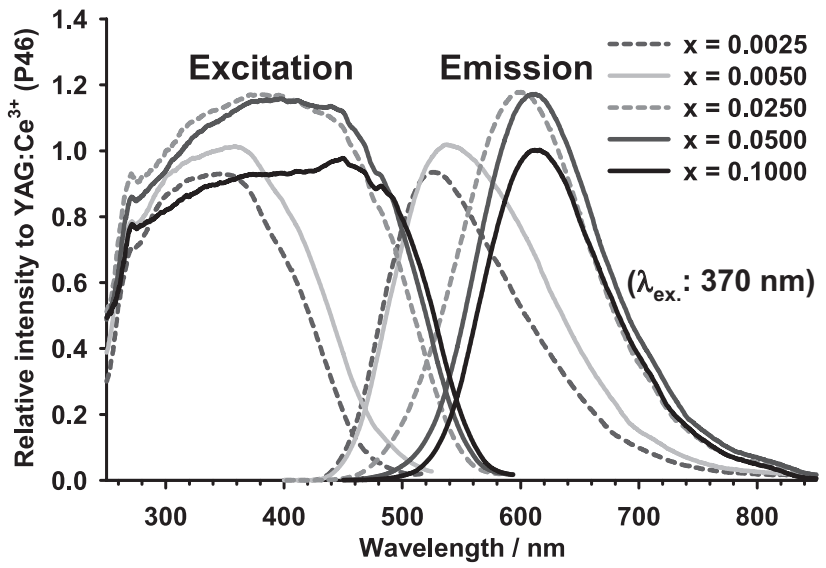

Fig. 7 Emission spectra of $\mathrm{Ca}_{1-x} \mathrm{Sr}_{1-x} \mathrm{Eu}_{2 \mathrm{x}} \mathrm{SiO}_{4}$ with $\mathrm{Eu}^{2+}(\mathrm{x})$ at 0.0025 , $0.0050,0.0250,0.0500$ and 0.1000 , excited at $370 \mathrm{~nm}$. The excitation spectra that were measured by monitoring at the maximum emission wavelengths are also shown.

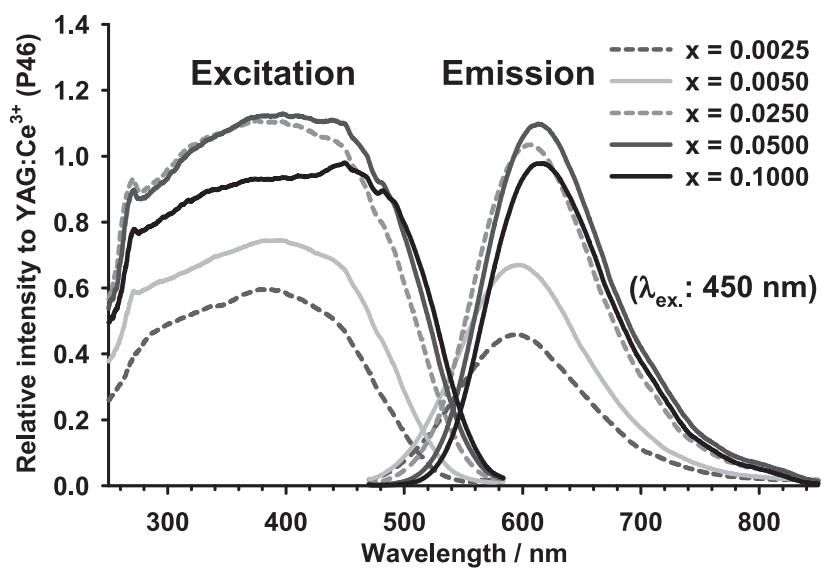

Fig. 8 Emission spectra of $\mathrm{Ca}_{1-x} \mathrm{Sr}_{1-\mathrm{x}} \mathrm{Eu}_{2 \mathrm{x}} \mathrm{SiO}_{4}$ with $\mathrm{Eu}^{2+}(\mathrm{x})$ at 0.0025 , $0.0050,0.0250,0.0500$ and 0.1000 , excited at $450 \mathrm{~nm}$. The excitation spectra that were measured by monitoring at the maximum emission wavelengths are also shown.

および酢酸ユーロピウム $\left(\mathrm{Eu}\left(\mathrm{CH}_{3} \mathrm{COO}\right)_{3}\right)$ の各水溶液を用 意し, 所望の化学組成に応じて混合し擋拌した. 攪拌後, $50{ }^{\circ} \mathrm{C}$ で静置するとゲル化した，続いて，得られたゲルをド ライチャンバー内に入れ， $-30{ }^{\circ} \mathrm{C}$ まで泠却し，真空に引き， 温度を 20 時間かけて $30^{\circ} \mathrm{C}$ まで徐々に上昇させることで, 凍結乾燥された前駆体粉末を得た。これを, $1000{ }^{\circ} \mathrm{C}, 12$ 時間, 大気下で仮焼成し,さらに $1200^{\circ} \mathrm{C}, 4$ 時間, $\operatorname{Ar}(96 \%)-\mathrm{H}_{2}$ （4\%）ガス䨌囲気下で還元焼成処理を行い，最終生成物を得 た。 なお，還元焼成の際，結晶性の向上及び結晶欠陥を減ら す目的で, フラックスとして $20 \mathrm{wt} \%$ の塩化バリウム二水和 物 $\left(\mathrm{BaCl}_{2} \cdot 2 \mathrm{H}_{2} \mathrm{O}\right)$ を混合し, 還元焼成処理を行った.

異なる $\mathrm{Eu}^{2+}$ 濃度で合成した $\mathrm{Ca}_{1-\mathrm{X}} \mathrm{Sr}_{1-\mathrm{x}} \mathrm{Eu}_{2 \mathrm{X}} \mathrm{SiO}_{4}(\mathrm{x}=0.0025$, $0.0050,0.0250,0.0500,0.1000)$ の励起・発光スペクトルを Fig. 7 およびFig. 8 に示す.ここで励起波長は, それぞれ波長 $370 \mathrm{~nm}$ および $450 \mathrm{~nm}$ である。 まず，励起スペクトルの波長範囲は $\mathrm{Eu}^{2+}$ 濃度の増加に伴い長波長側へ拡張し, 特に $\mathrm{x}=0.1000$ の ときの最大励起波長は $450 \mathrm{~nm}$ であった。一方, 励起スペク トルの場合と同様に, 発光スペクトルの最大発光波長は $\mathrm{Eu}^{2+}$ 
濃度の増加とともに長波長側へシフトし，特に, $\mathrm{x}=0.0500$ および 0.1000 において，波長 $610 \mathrm{~nm}$ 付近を中心とする $\mathrm{Eu}^{2+}$ の $4 \mathrm{f}^{7}-4 \mathrm{f}^{6} 5 \mathrm{~d}^{1}$ 遷移に対応する強いブロードの発光が確認でき る。この $\mathrm{Eu}^{2+}$ の低濃度領域で観測される緑色発光から高濃 度領域で観測される赤色発光への変化については, リード物 質である $\alpha^{\prime}-\mathrm{CaSrSiO}_{4}$ 内に存在する結晶学的に異なる二種類 の歪んだ $\mathrm{Ca}$ サイト $[\mathrm{Ca}(1)$ および $\mathrm{Ca}(2)$ サイト $]$ への $\mathrm{Eu}^{2+}$ の 置換が深く関係すると考えている ${ }^{21,28,29)} . \mathrm{Ca}(2)$ サイトの平均 $\mathrm{Ca}-\mathrm{O}$ 距離は, $\mathrm{Ca}(1)$ サイトに比べて極めて短いことが報告 されており, $\mathrm{Ca}^{2+}$ に比べてイオン半径の大きい $\mathrm{Eu}^{2+}$ が $\mathrm{Ca}(2)$ サイトへ置換した場合, Eu-O 間の相互作用は強くなること が予想される ${ }^{21,29)}$ ，加えて， $\mathrm{Eu}^{2+}$ はサイズの大きい $\mathrm{Ca}(1)$ サ イトへ優先的に置換するが, $\mathrm{Eu}^{2+}$ 置換量の増加に伴い, サ イズの小さい $\mathrm{Ca}(2)$ サイトにも置換していく．この点は, $\mathrm{CaSrSiO}_{4}$ の類似構造である $\mathrm{Ca}_{2-\mathrm{x}} \mathrm{Eu}_{\mathrm{x}} \mathrm{SiO}_{4}$ の結果からも予想で きる ${ }^{29)}$. 以上のことから, 低 $\mathrm{Eu}^{2+}$ 濃度の試料で観測された緑 色発光は主に $\mathrm{Ca}(1)$ サイトへ置換した $\mathrm{Eu}^{2+}$ から発光であり， $\mathrm{Eu}^{2+}$ 濃度の増加に伴い出現する赤色発光は $\mathrm{Ca}(2)$ サイトに置 換した $\mathrm{Eu}^{2+}$ から発光であると考えることができる。なお， 青色 LED の励起範囲 $(450 \mathrm{~nm})$ で励起したときの発光ピー ク（最大発光波長： $615 \mathrm{~nm}$ ) は, 市販黄色蛍光体 $\mathrm{YAG:Ce^{3+ }}$ （P46）の最大発光強度（励起波長：460 nm）を $100 \%$ とし た場合，若干高い $110 \%$ を示した，同組成の蛍光特性につい ては，既往の研究においても検討が行われてきたが，作製さ れた試料の発光ピークはいずれも $600 \mathrm{~nm}$ を超える赤色発光 を示すことはなかった ${ }^{30-32)}$ 。この理由に関しては明確な解釈 は得られていないが, 現時点で我々は固相反応法を用いたこ とによる $\mathrm{Eu}^{2+}$ の分散性の低さを理由として挙げている ${ }^{21)}$ 。 ず, $\mathrm{Eu}^{2+}$ 濃度の濃い領域では緑色発光も赤色発光の両発光と も濃度消光により微弱になるが, $\mathrm{Eu}^{2+}$ 濃度の薄い領域では緑 色発光が強くなることが予想できる。.さらに， $\mathrm{Eu}^{2+}$ 濃度の分 布が中間の場合，赤色発光の観測が期待できるが，既報にお いて明確な赤色発光が確認されてないことを考えると，不均 一な試料のため，そのような中間的な濃度分布を持つ領域は 試料内には非常に少なく，赤色発光はほとんど観測できな いか, もしくは緑色発光の長波長側に裾のような状態で観 測されるといったことが予想される，加えて，主相である $\mathrm{CaSrSiO}_{4}$ 相以外の不純物相の析出も予想され, 発光に寄与 しない $\mathrm{Eu}^{2+}$ や $\mathrm{Eu}^{3+}$ が試料内に多く存在することも予想され る。これに対して, 我々が用いたPGMSを用いた凍結乾燥 法は，Si を含むすべての金属イオンが原子レベルで化学的に 均一に混合されていることから，試料中の $\mathrm{Eu}^{2+}$ は均一に分 散性し，ほぼ完全な単相試料が得られたと解釈できる。つま り，PGMSを原料として使用することで， $\mathrm{Eu}^{2+}$ 濃度に応じた $\mathrm{CaSrSiO}_{4}$ 系本来の蛍光特性の発現が考えられる ${ }^{21)}$.これまで に広く知られた青色光励起・赤色蛍光体としては窒化物系赤 色蛍光体 $\left(\mathrm{CaAlSiN}_{3}: \mathrm{Eu}^{2+}\right.$ や $\mathrm{Sr}_{2} \mathrm{Si}_{5} \mathrm{~N}_{8}: \mathrm{Eu}^{2+}$ など） が挙げられる が33,34)，今回示した青色光励起により $600 \mathrm{~nm}$ を超える強い赤 色発光を示す酸化物蛍光体の報告例は非常に少なく，新しい 白色 LED 用赤色蛍光体としてその応用が大いに期待できる.

\section{4 まと め}

本報では，近年，白色 LEDへの応用が期待されるケイ酸 塩系蛍光体物質の新物質探索ならびに既知蛍光体の機能向上 を目的に，水溶液をべースにした合成を用いた当グループの 代表的な研究成果について紹介した。ケイ酸塩蛍光体に関し ては，主成分である $\mathrm{Si}$ の原料が酸化ケイ素粉末やケイ素系 アルコキシド（主にTEOS: tetraethoxysilane など）であり， 水溶液ベースの合成法によるアプローチは事実上不可能で あった。これに対して，我々は，GMSを水溶液ベースの蛍 光体合成に適用することで，溶液並列合成法よる迅速な候補 物質の探索や物質の高機能化に成功した。加えて，均一沈殿 法による新しいケイ酸塩系蛍光体物質の高輝度化と凍結乾燥 技術を用いた水溶液法によるケイ酸塩系青色光励起 ・ 赤色体 を見出すことに成功した. GMS は既存のケイ素アルコキシ ドの問題点を克服したケイ素原料であり，GMS を用いるこ とで，溶液法による合成により新規ケイ酸塩化合物の探索や 既知蛍光体の高機能化などを容易かつ効率的に行うことがで きる。また，GMSによる合成は今回紹介したケイ酸塩酸化 物だけなく, $\mathrm{Si}$ 含有の窒化物, 酸窒化物, 硫化物の前駆体合 成にも応用可能であり，例えば酸窒化物に関する研究例はす でに報告されている ${ }^{14,20)}$. GMS を用いた溶液合成プロセスが, ケイ酸塩蛍光体を含む多くの $\mathrm{Si}$ 含有セラミックス材料の高 純度合成法として広く利用される事を期して本稿を閉じたい.

\section{謝 辞}

本報を執筆するに当たり，東北大学・垣花研究室にて蛍光 体研究に取り組み，多くの研究成果を挙げていただいた旧ス タッフならびに多くの学生諸君に泚く感謝いたします。ま た，住友金属鉱山の小向哲史氏，高塚裕二氏には，共同研究 者として本研究全般に携わっていただくともに，多くの面で ご議論いただきました．ここに深く謝意を表します，本研究 の一部は, 文部科学省科学研究費補助金・新学術領域研究 「融合マテリアル」（平成 22-26 年度 : No. 2206）の援助を受 けて行われました。

\section{文献}

1) E. F. Schubert, J. K. Kim: "Solid-State Light Sources Getting Smart", Science, 308 (2005) 1274-1278.

2) H. Yamamoto: "Recent Progress toward Future Breakthrough in Phosphor Research”, Bull. Ceram. Soc. Japan, 41 (2006) 582-587.

3) K. Toda: "Phosphors for New Lighting System", Bull. Ceram. Soc. Japan, 41 (2006) 607-611.

4) H. Yamamoto: "Present Status and Prospect of Multinary Phosphor Materials," Oyo Buturi, 76 (2007) 241-251.

5) P. F. Smet, A. B. Parmentier, D. Poelman: "Selecting Conversion Phosphors for White Light-Emitting Diodes", J. Electrochem. Soc., 158 (2011) R37.

6) P. Dorenbos: "The $5 \mathrm{~d}$ Level Positions of the Trivalent Lanthanides in Inorganic Compounds”, J. Lumin., 91 (2000) 155-176. 
7) P. Dorenbos: "Energy of the First $4 \mathrm{f}^{7} \rightarrow 4 \mathrm{f}^{6} 5 \mathrm{~d}$ Transition of $\mathrm{Eu}^{2+}$ in Inorganic Compounds”, J. Lumin., 104 (2003) 239-260.

8) M. Kakihana, Y. Suzuki: “Aqueous Solution Process Utilizing Novel Water-Soluble Silicon Compounds-Development toward Synthesis of Phosphors with High Brightness-", Bull. Ceram. Soc. Japan, 44 (2009) 594-597.

9) M. Kakihana: "Synthesis of High-performance Ceramics Based on Polymerizable Complex Method", J. Ceram. Soc. Japan, 117 (2009) 857-862.

10) M. Kakihana, J. H. Kim, T. Komukai, H. Kato, Y. Sato, M. Kobayashi, Y. Takatsuka: "Exploration of New Phosphors using a Mineral-Inspired Approach in Combination with Solution Parallel Synthesis”, Opt. Photonics J., 03 (2013) 5-12.

11) Y. Suzuki, M. Kakihana: "Parallel Synthetic Exploration of $\mathrm{Tm}^{3+}$-Doped Alkaline-Earth Gallate Phosphors by use of Polymerizable Complex Method", J. Ceram. Soc. Japan, 115 (2007) 612-614.

12) Y. Suzuki, M. Kakihana: "Parallel Solution-Based Synthesis Approach for Search of Lanthanoid-Activated $\mathrm{Ca}_{2} \mathrm{SnO}_{4}$ Phosphor Materials”, J. Am. Ceram. Soc., 92 (2009) S168-S171.

13) M. Kakihana: "Sol-Gel Preparation of High Temperature Superconducting Oxides”, J. Sol-Gel Sci. Technol., 6 (1996) 7-55.

14) C. Yasushita, H. Kato, M. Kakihana: "Synthesis of an Oxynitride-Based Green Phosphor $\mathrm{Ba}_{3} \mathrm{Si}_{6} \mathrm{O}_{12} \mathrm{~N}_{2}: \mathrm{Eu}^{2+}$ via an Aqueous-Solution Process, using Propylene-Glycol-Modified Silane”, J. Inf. Disp., 13 (2012) 107-111.

15) Y. Suzuki, M. Kakihana: "Preparation of Water Soluble Silicon Compound and its Application for Synthesis of $(\mathrm{Y}, \mathrm{Ce}, \mathrm{Gd})_{2} \mathrm{SiO}_{5}$ Blue Emission Phosphor", J. Ceram. Soc. Japan, 117 (2009) 330-334.

16) N. Takahashi, Y. Suzuki, M. Kakihana: "Synthesis of $\mathrm{Zn}_{2} \mathrm{SiO}_{4}: \mathrm{Mn}^{2+}$ Green Emission Phosphor by Hydrothermal Gelation Method using a Novel Water Soluble Silicon Compound”, J. Ceram. Soc. Japan, 117 (2009) 313-315.

17) Y. Y. Luo, D. S. Jo, K. Senthil, S. Tezuka, M. Kakihana, K. Toda, T. Masaki, D. H. Yoon: "Synthesis of High Efficient $\mathrm{Ca}_{2} \mathrm{SiO}_{4}: \mathrm{Eu}^{2+}$ Green Emitting Phosphor by a Liquid Phase Precursor Method", J. Solid State Chem., 189 (2012) 68-74.

18) K. Yoshizawa, H. Kato, M. Kakihana: "Synthesis of $\mathrm{Zn}_{2} \mathrm{SiO}_{4}: \mathrm{Mn}^{2+}$ by Homogeneous Precipitation using Propylene GlycolModified Silane”, J. Mater. Chem., 22 (2012) 17272-17277.

19) J. H. Kim, H. Kato, M. Kakihana: "Control of $\mathrm{NaAlSiO}_{4}: \mathrm{Eu}^{2+}$ Photoluminescence Properties by Charge-Compensated Aliovalent Element Substitutions”, J. Inf. Disp., 13 (2012) 97-100.

20) J. H. Kim, H. Kato, M. Kobayashi, Y. Sato, M. Kakihana: "Synthesis of a Novel Bluish-Green Emitting Oxynitride $\mathrm{Ca}_{3} \mathrm{Al}_{8} \mathrm{Si}_{4} \mathrm{O}_{17} \mathrm{~N}_{4}: \mathrm{Eu}^{2+}$ Phosphor in a $\mathrm{CaAl}_{4-\mathrm{x}} \mathrm{Si}_{\mathrm{x}} \mathrm{O}_{7-\mathrm{x}} \mathrm{N}_{\mathrm{x}}$ Solid Solution System", Opt. Photonics J., 3 (2013) 29-33.

21) S. Tezuka, Y. Sato, T. Komukai, Y. Takatsuka, H. Kato, M.
Kakihana: "Eu ${ }^{2+}$-Activated $\mathrm{CaSrSiO}_{4}$ : a New Red-Emitting Oxide Phosphor for White-Light-Emitting Diodes", Appl. Phys. Express, 6 (2013) 072101.

22) J. H. Min, T. Yamaguchi, H. Kato, M. Kobayashi, H. Yamane, M. Kakihana: "Development of Two Novel Eu ${ }^{2+}$-Activated Phosphors in the Na-Sc-Si-O System and their Photoluminescence Properties”, J. Lumin., 154 (2014) 285-289.

23) J. A. Gonzalez-Ortega, E. M. Tejeda, N. Perea, G. A. Hirata, E. J. Bosze, J. McKittrick: "White Light Emission from Rare Earth Activated Yttrium Silicate Nanocrystalline Powders and Thin Films", Opt. Mater., 27 (2005) 1221-1227.

24) T. Komukai, Y. Takatsuka, H. Kato, M. Kakihana: "Luminescence properties of $\mathrm{BaZrSi}_{3} \mathrm{O}_{9}$ :Eu synthesized by an aqueous solution method", J. Lumin., 158 (2015) 328-332.

25) T. Abe, K. Toda, K. Uhematsu, M. Sato, T. Ishigaki, K. B. Sung, D. S. Jo, T. Masaki, D. H. Yoon: "Synthesis and the Luminescent Properties of Silicate $\mathrm{NaAlSiO}_{4}: \mathrm{Eu}^{2+}$ Phosphor using $\mathrm{SiO}$ Powder as a Silica Source”, Key Eng. Mater., 582 (2013) 214-217.

26) A. L. N. Stevels, A. T. Vink: "Fine Structure in the Low Temperature Luminescence of $\mathrm{Zn}_{2} \mathrm{SiO}_{4}: \mathrm{Mn}$ and $\mathrm{Mg}_{4} \mathrm{Ta}_{2} \mathrm{O}_{9}: \mathrm{Mn}$, J. Lumin., 8 (1974) 443-451.

27) X. Ouyang, A. H. Kitai, T. Xiao: "Electroluminescence of the Oxide Thin Film Phosphors $\mathrm{Zn}_{2} \mathrm{SiO}_{4}$ and $\mathrm{Y}_{2} \mathrm{SiO}_{5}$ ", J. Appl. Phys., 79 (1996) 3229-3234.

28) M. Catti, G. Gazzoni, G. Ivaldi: "Order-Disorder in the $\alpha$ '$(\mathrm{Ca}, \mathrm{Sr})_{2} \mathrm{SiO}_{4}$ Solid Solution: A Structural and StatisticalThermodynamic Analysis", Acta Cryst., B40 (1984) 537-544.

29) Y. Sato, H. Kato, M. Kobayashi, T. Masaki, D. H. Yoon, M. Kakihana: "Tailoring of Deep-Red Luminescence in $\mathrm{Ca}_{2} \mathrm{SiO}_{4}: \mathrm{Eu}^{2+}$, Angew. Chem. Int. Ed., 53 (2014) 7756-7759.

30) Z. -J. Wang, Z. -P. Yang, Q. -L. Guo, P. -L. Li, G. -S. Fu: "Luminescence Characteristics of $\mathrm{Eu}^{2+}$ Activated $\mathrm{Ca}_{2} \mathrm{SiO}_{4}$, $\mathrm{Sr}_{2} \mathrm{SiO}_{4}$ and $\mathrm{Ba}_{2} \mathrm{SiO}_{4}$ Phosphors for White LEDs", Chin. Phys. B, 18 (2009) 2068-2071.

31) H. Yu, Y. Lai, G. Gao, L. Kong, G. Li, S. Gan, G. Hong: "Photoluminescence and Energy Transfer Studies on $\mathrm{Eu}^{2+}$ and $\mathrm{Ce}^{3+} \mathrm{Co}$-Doped $\mathrm{SrCaSiO}_{4}$ for White Light-Emitting-Diodes”, J. Alloys Compd., 509 (2011) 6635-6639.

32) W. J. Park, Y. H. Song, D. H. Yoon: "Synthesis and Luminescent Characteristics of $\mathrm{Ca}_{2-\mathrm{x}} \mathrm{Sr}_{\mathrm{x}} \mathrm{SiO}_{4}: \mathrm{Eu}^{2+}$ as a Potential GreenEmitting Phosphor for Near UV-White LED Applications", Mater. Sci. Eng. B, 173 (2010) 76-79.

33) K. Uheda, N. Hirosaki, H. Yamamoto: "Host Lattice Materials in the System $\mathrm{Ca}_{3} \mathrm{~N}_{2}-\mathrm{AlN}-\mathrm{Si}_{3} \mathrm{~N}_{4}$ for White Light Emitting Diode", Phys. Status Solidi, 203 (2006) 2712-2717.

34) R. Xie, N. Hirosaki, T. Suehiro: F. Xu, M. Mitomo, “A Simple, Efficient Synthetic Route to $\mathrm{Sr}_{2} \mathrm{Si}_{5} \mathrm{~N}_{8}: \mathrm{Eu}^{2+}$-Based Red Phosphors for White Light-Emitting Diodes", Chem. Mater., 18 (2006) 5578-5583. 